\section{A Teacher's Dilemma in Creating a Democratic and Socially Just Classroom}

\author{
Su Jung Um*
}

\begin{tabular}{ll}
\hline Received: & 22 March 2019 \\
Revised: $\quad 30$ May 2019 \\
Accepted: $\quad$ 10 June 2019 \\
ISSN: 1307-9298 \\
Copyright (C) IEJEE \\
www.iejee.com
\end{tabular}

DOI: $10.26822 /$ iejee.2019553339

\begin{abstract}
This qualitative case study aims to understand teaching experiences of a recent graduate of a social justice-oriented program in the U.S. It examines what dilemma(s) the teacher reports and how she copes with them. In-depth interviews and document collections are used as the means of data construction. Thematic and dialogic/performance analysis methods are utilized for data analysis. The analysis of the teacher's case demonstrates that the competing discourses circulating in the school produce significantly different ideas of what a "good" teacher is and does; the differences constituted through the discourses create contradictions affecting the teacher's lived experiences. The teacher reports her struggle to become a critical and, yet, unbiased teacher. It also shows that the teacher deals with the dilemma by re-interpreting the discourses that she finds limiting. This study confirms and, yet, extends the exiting body of research as it sheds lights on how the teachers' experiences are shaped by and, simultaneously, re-frame the discourses surrounding her. Future directions for research and practice are discussed.
\end{abstract}

Keywords: Teaching for Social Justice, Democratic Education, Teacher Education, Case Study

\section{Introduction}

Schools have been failing to address educational equity. Researchers have reported the disparities in funding, monetary and technological resources, numbers of certified teachers, instruction quality, and educational outcomes between students with and without the advantages conferred by race, gender, class, language, and dis/ability (Anyon, 1997; Apple, 2006; Darling-Hammond, 1997; Darling-Hammond, 2004; Ferguson, 2000; Giroux, 1997; Rothstein, 2004; Valle \& Connor, 2011; Zollers, Albert, \& Cochran-Smith, 2000). Within this context, increasing numbers of scholars consider teacher education to be a crucial element in building a more "just" society (Athanases \& Martin, 2006; Cochran-Smith \& Fries, 2005; Cochran-Smith, Shakman, Jong, Terrell, Barnatt, \& McQuillan, 2009; Hollins \& Guzman, 2005; McDonald \& Zeichner, 2009).

Conceptualizing teaching and teacher education in terms of social justice has been an important agenda for educational researchers and teacher educators. The social justice agenda aims to prepare teachers to be professional educators and activists who are committed to dismantling social and educational inequities (Cochran-Smith, 2005; Zeichner, 2003). It conceives teacher education as a crucial factor in development of more equitable and just school and society. Teacher education for social justice, however, is interpreted through a range of different practices and values with multiple philosophical and theoretical groundings. Teacher education programs highlight various perspectives including, but not limited to, multiculturalism, culturally relevant pedagogy, anti-oppressive education, and inclusive education to implement their commitments to social justice.

Sleeter (2009) explains teacher education intended to promote social justice as being constituted by the following three strands:

(1) [S] upporting access for all students to high-quality, intellectually rich teaching that builds on their cultural and linguistic backgrounds; (2) preparing teachers to foster democratic en- gagement among young people; and (3) preparing teachers to advocate for children and youth by situating inequities within a systemic sociopolitical analysis. (p. 611)

A number of teacher preparation programs in the U.S. have made structural and curricular changes with commitments to social justice (Cochran-Smith, 2005). Most teacher education programs have added courses that incorporate some combination of the above and/or other relevant perspectives (Darling-Hammond, 2006; Zeichner, 2006); some programs have required clinical experiences with diverse students (Ladson-Billings, 2001). In social justice-oriented preservice programs, first, teachers are prepared to possess a body of content and pedagogical knowledge; however, they also learn to critique the very idea of knowledge by considering whose knowledge is valued for whom and for what purpose (Cochran-Smith, 2008). Second, teachers are encouraged to actively interrogate their own interpretive framework(s) through which they understand their students, make decisions, and form relationships because it is closely linked with students' learning and life opportunities (Cochran-Smith, 2008). Third, teachers are prepared to understand and utilize guiding pedagogical principles that can foster justice such as developing caring relationships with students (Noddings, 1984), designing culturally relevant instruction (Gay, 2000; Ladson-Billings, 1995), and enabling students to acquire access to the dominant culture of power and to critique the dominant culture itself (Nieto, 2003). Lastly, teachers are expected to become activists as well as educators using a political consciousness (Cochran-Smith, 2008).

While much attention has been paid to how preservice teachers are prepared in social justice-oriented teacher education programs, there is a scarcity of studies investigating how their learning is translated into practice (Dover, Henning, \& Agarwal-Rangnath, 2016; Grant \& Agosto, 2008; Um, 2019). The exiting literature reports that teachers generally acknowledge and struggle with the disconnection between ideals of social justice and their day-to-day teaching contexts. 
Some studies present that teachers encounter dilemmas associated with their limited capacity to enact a vision of social justice in their school contexts (Agarwal, Epstein, Oppenheim, Oyler, \& Sonu, 2010; Chubbuck \& Zembylas, 2008; Paugh, 2006; Nixon, 2010). This study seeks to contribute to the body of knowledge by investigating a case of a teacher who experiences dilemmas in a space where competing discourses meet and clash.

In this study, I examine teaching experiences of a recent graduate of a social justice-oriented program in the U.S. I seek to pay more attention to the ways in which the teacher's experiences are discursively constituted by the competing discourses that surround her. The guiding questions are as follows: a) What dilemma(s) does the teacher report as a graduate from a social justice-oriented program? b) How does the teacher cope with the dilemma(s)?

\section{Method}

This qualitative case study involved a female elementary school teacher, Lauren (pseudonym), who is a white Jewish woman in her mid-twenties. At the time of the research, she was teaching in a 4 th grade team teaching classroom at Central Elementary School (pseudonym) located in an area that is a technically city but more like a large suburb. The Central Elementary School enrolled approximately 400 students $(67 \%$ White, $11 \%$ Hispanic, $10 \%$ Asian, and $6 \%$ African American). Almost $10 \%$ of the students were English Language Learners. As the school district had a state funded desegregation program, some of the African American and Latino students in her class were bused to attend the school. The Central Elementary School comprised kindergarten through $5^{\text {th }}$ grade, and there were three or four classes per grade level. The school had two team teaching classrooms, one in 4 th grade and the other in $5^{\text {th }}$ grade.

Lauren graduated from a social justice-oriented elementary preservice program at a large university in Northeastern State in the U.S. The preservice program led to an M.A. degree and teacher certification(s). It was a dual-certification program, meaning that students could pursue either single-certification in elementary education or dual-certification in both elementary and teaching students with disabilities in grades 1-6. The teacher education program highlighted its commitments to social justice. Through various courses, assignments, and student teaching experiences, the program sought to prepare their preservice teachers to acquire knowledge about the various forms of oppression operating in schools and society, while also developing their pedagogical skills to promote educational and social equity. The selection of the preservice program was a matter of access.

I used in-depth interviews as the primary means of data construction. I embarked upon a series of seven interviews with Lauren from January 2013 to June 2013. The interviews were approximately 60-90 minutes in length and arranged at her convenience on a regular basis once every two to three weeks. All interviews were audiotaped and transcribed. In addition, I collected documents that Lauren generated for instruction during the 2012-2013 academic year as additional data for this study. The documents included teacher-produced curricula, lesson plans, lesson materials, classroom charts, and class blogs. The data were analyzed in two ways. First of all, I conducted thematic analysis that focused on what the participant reported regarding the issues central to this study (Riessman, 2008). In addition, dialogic/performance analysis was used to examine how broader contexts informed the ways in which the participant constructed and interpreted her teaching experiences (Riessman, 2008). For dialogic/ performance analysis, I identified specific discourses that circulated in statements made by the participant and examined how her accounts about her teaching experiences drew on and reinforced the discourses.

\section{Results: Lauren's Story}

\section{Journey to Becoming a Teacher}

Growing up, Lauren always knew she would be a teacher. In many videos her mother recorded for Lauren when she was young, she was lining up her dolls and teaching them. She remembered how much she enjoyed interacting and connecting with younger people. As a student, she always loved school. Not only did she feel comfortable, but she also excelled in school. Yet, her decision to be a teacher might not be explained without her commitment to promoting social equity.

Once I really started to think more about equity, I started to really see that this [teaching] was my calling because there's a lot of ways to try to make the world a more equitable, fair, just, and right place, which is really what I wanted to do. But, this was a choice I made that I think linked up with my interests.

She grew up in a family dedicated to addressing various issues of in/equity. Her grandparents were active advocates in the Civil Rights Movement; her grandmother was at Martin Luther King's "I Have a Dream" speech as a supporter. Her maternal grandparents worked on fair housing committees in New Jersey, fighting for equal housing for people who were racial profiled. Lauren said, "So, you could say it's in my blood to think about these kinds of things."

While attending public schools from kindergarten to college, Lauren felt how inequity exists along the lines of gender, race, ethnicity, class, religion, language, nationality, and disability in school. She remembered how she felt uncomfortable when she noticed her peers' self-segregation along "racial lines" in her middle school cafeteria and how she felt strange when she transferred to the wealthy, "white" high school. Although she was engaged with and wrestled with the issues of difference and in/equity in her middle and high schools, she did not frame the issue in a way that she does now until she entered the college. It was one of her college courses that offered her the framework to make sense of her experiences. Majoring in psychology and minoring in education, she took a course with a faculty member who was involved in the Freire Project launched by the Faculty of Education in the college. Through the course, she read articles like Peggy McIntosh's White Privilege: Unpacking the Invisible Knapsack. She appreciated the opportunities that pushed her to question what she had taken for granted.

After graduating from the college, Lauren applied for the elementary preservice program, being certain that she wanted to be a teacher. She was intrigued by the ways in which the program described its commitments to social justice. The preservice program offered her an "innovative and cutting-edge environment to learn." What she learned in the program was eye-opening to her. Lauren had many "aha" moments that stimulated her practically and intellectually. Going through the program, Lauren could analyze how school systematically privileges some students and marginalizes others more critically. Lauren could form relationships with people that she could consider her "colleagues for years down the road." She met many people who could share similar commitments and provide emotional supports and informational resources. Lauren graduated from the preservice program in February 2012 with both elementary and special education teacher certificates. 
Lauren started her teaching career in a kindergarten self-contained classroom at a public elementary school. Lauren chose to work in the setting that she regarded as exclusionary because she thought it would be an "interesting and powerful way to push up against that system, to kind of fight it from within." She strived to pull students out of her self-contained classroom and place them into a space where they could learn with their non-disabled peers. However, it did not take too long for Lauren to realize that the existence of her self-contained classroom itself impeded her efforts to promote inclusivity in the school. Her students remained as "guests" in the general education classrooms in which they were placed. She could not get rid of the feeling that she was reinforcing the status quo by the very nature of her position. She felt torn working in the environment. After spending a semester at the school, she decided to quit the job. In September 2012, Lauren moved to Central Elementary School hoping for a working environment more aligned with her educational philosophy.

\section{Ideals of Democratic Education}

Lauren taught in a $4^{\text {th }}$ grade team teaching classroom at Central Elementary School at the time of the research. Her co-teacher was Stacey who graduated from the same teacher education program. Lauren strived to cultivate a classroom community that was genuinely democratic. Lauren believed that her ideals of democratic education was the manifestation of the commitment of her preservice program to social justice. She hoped that every student could be positioned as a valued member regardless of their differences. Lauren thought some students are often positioned as less able, not interested in learning, and problematic by various taken-for-granted school routines and structures. To cultivate a democratic community, Lauren recognized the importance of disrupting such "old habits" as ability-based grouping, conventional homework assignments, and top-down disciplinary strategies.

Lauren often used such phrases as "giving voice" and "being heard" to describe her ideals of democratic education. For Lauren, democratic community should be built on every member's right to speak and to be heard. One of her goals as a teacher was to help her students develop their voice for "stand[ing] up for each other, raising concerns, talking about an issue, pushing back against something the teacher says even, or initiating a class vote around something." Lauren hoped to undo the top-down schooling practices that might silence students and to enable them to be "authors" of their own world. Moreover she taught her students to listen deeply to others. In her class, there were on-going conversations around what it would mean to be heard and what it would look like. She often reminded her students that "they have a voice that is valuable, they have a story to be told, that others want to hear it, and others will wait for that story to be told and be patient around it."

Moreover, Lauren associated democratic education with a universally designed teaching approach that could grant all students access to learning experiences regardless of their cultural, racial, and linguistic backgrounds, preferred modes of learning, and disability. The version of democratic education that she envisioned would not privilege some students over others based on their conformity to the "normal" ways of learning. Thus, Lauren sought to understand each student's strengths, wants, and needs through different types of surveys and to make pedagogical decisions based on such information. Allowing diverse ways of engaging with materials and exhibiting their understanding were examples of her practices that aimed to promote democratic education. In her $4^{\text {th }}$ grade classroom at the Central Elementary School, Lauren hoped to make sure that her students could feel a sense of community, recognize their right to speak and to be heard, and participate in accessible learning activities.

\section{Becoming a Critical and Unbiased Teacher}

Lauren did not view school as an educational institution that could promote meritocracy, interest-neutrality, and equal opportunity. For her, school was a place where certain groups of people were privileged over others. She was committed to altering her own and others' discriminatory beliefs and practices that might replicate unequal power relations. Lauren attributed this commitment partly to her preservice program, which encouraged her to see herself as a change agent working to transform the unjust educational and social system. Lauren had an impression that the program expected its graduates to "have conversations around issues like race, ethnicity, privilege, socioeconomic status, gender, sexuality with their students" and to develop a critical consciousness about their surroundings.

Although she recognized the importance of promoting students' critical thinking, Lauren found herself feeling uneasy about openly discussing social issues with her students. Lauren did not want her students "questioning everything with regard to race or disability just because I [she] said so." Lauren stated:

By avoiding a social justice framework in the way I've conceived of it here as a way of questioning of these relations, cross relations, power dynamics, I think I move away from imposing [my] political views upon students and instead move more toward having students enter into a dialogue with me, some kind of a conversation that goes back and forth, in which they experience a freedom to agree or disagree. Today a student openly disagreed with me, a student who rarely speaks up. An English language learner who has a communication disability, labeled as such, and I find, I found that experience to be exactly how I perceive a democratic education. I made a comment about how, if there were bullying situations that, if other people stood up in a group against a bully, it would be a way to make the bully stop bullying behavior, and this student said, "I disagree because I don't think that would stop a bully. I think they're stronger than that." And, I told him how much I appreciated him for disagreeing with me. In May of my first full year teaching, I feel like that's a huge accomplishment that I've cultivated a community and relationships with students where they feel like they can disagree with me.

Although she understood the importance of developing students' critical thinking skills, Lauren was afraid she would impose her political views when she, as a class authority, revealed her opinions on social issues. Lauren was nervous about the possibility of silencing her students who might have different ideas than hers. Lauren did not want her students to adopt her viewpoint passively. While I noticed her stance on this specific issue was constantly shifting throughout the research, Lauren, in that particular moment, thought that the social justice framework conflicted with her ideal of democratic education because it might threaten the freedom of speech that she strived to cultivate.

After the interview, the comment Lauren made about teaching for social justice haunted her. Lauren had to revisit her paradoxical feelings about it. After a conversation with Stacey about the issue, Lauren said:

My co-teacher and I had a different... had an interesting conversation about this a couple weeks ago, and she said, "But teaching for social justice is the right way to think," and I said, "Yeah, to us. And I agree it's the right way but it's not to everyone." And so, particularly people of I think certain political agendas are going to think differently about that. And there 
may be parents in our classroom who are raising their kids to have certain prejudices against certain types of people, and that's where I start to feel uncomfortable because of course don't want my students developing those kind of prejudices, but I also feel kind of uncomfortable intervening in parenting styles and trying to override that in a childhood education. And I guess some critical questions for me about what the role of an educator is in raising a child's thinking.

While Stacey, in their conversation, seemed to firmly believe that teaching for social justice would be the "right" way no matter what, Lauren was unsure. Lauren did not want to perpetuate the social relations and hierarchical dynamics situated in society. She did not want to leave the dominant viewpoint unchallenged in her classroom. Nevertheless, Lauren could not avoid feeling that she migh impose her own political viewpoint through the framework of teaching for social justice. She was also uncertain about what she should do when parents might not want their children persuaded by her political view. The uncer tainty over what role she should play as a teacher made Lauren hesitate when pursuing what she thought was social justice education.

Approximately four weeks after she expressed her dis comfort with teaching for social justice, which, she assumed, required discussions around social issues, Lauren mentioned that Stacey and she started to do "some of the first real like social justice work because there have [had] been some shifts in my [her] thinking." Lauren elaborated how her view had been changed.

When I took this job almost a year ago now, I was so over whelmed and just in survival mode that I couldn't get to some of this more critical and creative thinking. And, kind of once I hit my one-year mark in teaching, like, maybe for me around February-March, I don't know, maybe more like April, I felt a real turning point not just in, like, social justice but in other kinds of lesson planning and teaching as well to become more of the teacher I want to be. So I think some of it is just developmental of a learning curve. I think right now my thinking... It has shifted a lot but right now my thinking is that there is merit to including and incorporating social justice as a thread and an idea throughout teaching and kids' education. I don't see it is as needing to be as central though as I think the preservice program made it out to be infused as profusely as I think it was made out to be at the preservice program. [What] I think more importantly is: how do you get kids to have deep conversations about anything? How do we get them to interact thoughtfully and productively with each other? How do you cultivate a community of thinkers and listeners where people are respected, where kids feel comfortable voicing their opinions?

Lauren assumed that the change occurred because she could get out of the "survival mode." She felt that she had more time and energy, which she did not have before as a newly appointed teacher, to incorporate issues of social in/justice into her lessons. As she could move to the next learning stage, Lauren started to see the benefit of teaching about issues of social in/justice. However, Lauren did not believe that it should be the central theme of her teaching as her preservice program encouraged. Instead Lauren aimed to create a space where her students could think about various issues deeply, stand up for their own beliefs, and respect different opinions. Lauren explained how the shift in her thinking had informed her pedagogical approach.

Students read books that had similar themes around discrimination, racism, um, immigration. And, we had what we called an Upstanders Conference. [...] We really struggled because that seemed like pushing a political agenda. That kind of thinking around how you're not going to be racist or how you're not going to discriminate, and that also felt a little bit preachy. And, we didn't think it would be so rich because we thought the kids would just kind of be saying what they thought we wanted to hear instead of just really having a full out conversation of some of these critical issues. So we really struggled with how we were going to bring together all these themes that they'd been talking about. Eventually, we settled on a series of statements that tied into our class read-aloud and had strands or threads of social justice woven into them, but they weren't explicit. They were disguised in the context of the book.

The Upstanders Conference was planned to help students critically understand the world around them. However, Lauren noticed that the conference became "preachy." She did not want to cultivate a black and white morality in her students' minds; she did not want her students to construct the simple binary of justice versus injustice. Instead, she sought to encourage them to form their own stance on an issue and communicate their opinion with others respectfully. To make it happen, she had to make what was good/bad or just/unjust less dichotomous. For example, they read a book: The Watsons Go to Birmingham - 1963. The book was about a family traveling to Birmingham in 1963 when there were racial riots and bombings. After reading the book, Lauren presented the following statements to her students: a) The character in the book who has the most courage is Kenny, b) Mrs. Davidson should have given Joey a black doll rather than a white one, c) Kenny shouldn't have shared his lunch with Rufus, d) When he beat up Larry Dunn, Bryon gave him what he deserved for stealing, and e) Byron shouldn't have been punished for his choice of hairstyle.

Then, the students decided whether they agreed or disagreed with each statement and made an argument for their point of view. They were allowed to switch sides. Through this strategy, Lauren attempted to avoid imposing her opinions on the students and pushing her political agenda. Lauren was satisfied with how her students were engaged in the topics. They had a "meaty discussion" over the issues of social in/justice "within a context that they were able to access." Lauren thought this approach was able to elicit a multiplicity of views. Many of the students questioned their peers who had different opinions, and they reconsidered their own understanding through the discussion. Lauren said, "This is really where I see democratic education entering into my philosophy.

\section{Discussion}

Lauren exhibited a feeling of discomfort about incorporating controversial social issues into curriculum, which she conceived as an important part of social justice education. It appeared, to me, that it was an effect of the competing discourses available to her. The discourse of progressive education, the discourse of critical pedagogy, and the current conservative discourse of critical thinking played an important, not complete, role in making controversial social issues uncomfortable. Although I acknowledge these discourses cannot be pinned down for definitive purposes because they are constantly re-inscribed with new meanings, I unavoidably essentialize them in order to explain what I mean by them and how they might inform Lauren. The discourse of progressive education, first of all, has been circulating within educational fields in the U.S. since early twentieth century. John Dewey's ideas on democratic life and education in works like The School and Society (1899), The Child and the Curriculum (1902), and Democracy and Education (1916), offered a significant basis for the discourse of progressive education. Ironically, there have been criticisms of how Dewey is misrepresented through the discourse of progressive education (Cahn, 1988; Fallace, 2011; Stanley \& Nelson, 1994; Weiss, DeFalco, \& Weiss, 2005). For example, according to Cahn (1988), Dewey explicitly expressed his opposition to progressive education for its rejection of teacher's pedagogical authority and romanticism of student caprice. Weiss and 
her colleagues (2005) argue that Dewey's ideas have been misinterpreted as making students' life experience as end unto itself rather than as a means for their meaningful interaction with subject matters. The discourse of progressive education has offered many teachers who identified themselves as progressive with a convincing rationale for their antiauthoritarian practices. Progressive educators emphasize the value of respecting individual students' differences to create meaningful and joyful learning experiences. They also seek to actively engage young people in decision-making about numerous areas of classroom operations. As a progressive teacher constituted through this discourse, Lauren had explicit commitments to creating a democratic classroom community in which, each student's diverse ideas, abilities, interests, and needs would be respected.

Another discourse that impacted Lauren was the discourse of critical pedagogy. Influenced by thoughts of Paulo Freire, there have been educators who conceptualize teaching as a means of social reform (e.g., Henry Giroux, Michael Apple, Peter McLaren). They assume that schools reflect and replicate power-laden, often hierarchical, structures of the society and that schools should be institutions that prepare citizens to create a more equitable and just society. Within this discourse of critical pedagogy, the teacher should play a role in making curricular changes to enable students to critically think through various social and political issues. The type of criticality promoted by this discourse involves raising questions that are naturalized and, thus, not generally asked. In other words, the criticality associated with the discourse of critical pedagogy endorses questions like "what made the situation as it is, who made the situation as it is, and whose interests are served by the status quo" (Applebaum, 2009, p. 397).

Lauren acknowledged that this discourse of critical pedagogy circulated in her teacher education program and imposed a certain expectation on her; that is, she, as a teacher, should enable her students to pay attention to various forms of injustice deeply entrenched in the taken-for-granted structures of the society using curricular changes. Recognizing historically embedded inequities in schools and in the society, Lauren desired to contribute to redressing them as a teacher. Yet, she did not feel comfortable incorporating controversial social issues into the curriculum. Lauren was aware of the unequal weight and legitimacy between her and her students' voices. Thus, she worried that she might replicate the authoritarian school culture by starting discussions on controversial issues and revealing her opinion. Lauren felt the tension between the discourses of progressive education and critical pedagogy. Lauren was uncertain about using her institutionally given power to disrupt power relations. Lauren's concern partially reflects critical pedagogues' on-going conversations about the ethical dilemmas created by "the disparity between the ideals of participatory democracy and the realities of social inequality" (Boler, 2004, p. viii).

More recently, conservative activists and politicians have produced a discourse that uses languages of progressive education and critical pedagogy but in a quite different way (Laats, 2014). Pointing to the traditional, top-down, and autocratic features of public schools, they worry that students are subject to indoctrination in the guise of education. Today's social conservatives call for critical thinking skills in school that enable students to analyze given information, form their own opinions, and respectfully respond to other ideas on controversial issues. They argue that students must have freedom to dissent from teachers' intellectual impositions. Laats (2014) lists various cases in which social conservatives have attempted to introduce school laws that develop critical thinking and prohibit in- tellectual discrimination against those who have different ideas including conservative leanings (e.g, Senate Bill 1765 in Oklahoma, House Bill 207 in Virginia, House Bill 1587 in Missouri).

This discourse of critical thinking posits teacher as a nonpartisan referee, who ensures fair competition between multiple perspectives. When teachers use their authority to take a partisan role in classroom discussions about controversial issues, fair competition among diverse ideas is thwarted. This discourse uses the languages associated with progressive and critical educators but with the implicit purpose of preserving social norms (Laats, 2014). Lauren recognized that this discourse offered many people in her school and in the society with a "convincing" framework of critical thinking. Lauren was not sure what to do when the parents of her students accused her of using the classroom "as a political podium at the expense of intellectual diversity" (Applebaum, 2009, p. 377). This conservative discourse of critical thinking also informed Lauren's teaching experiences.

These discourses construct conflicting meanings of what a teacher is and does. Being located in a space where these discourses merged and clashed, Lauren struggled with negotiating among competing desires and demands, which were not separated but interconnected in complex ways. Lauren sought to become a progressive teacher who could mitigate autocratic school cultures and practices. She also hoped to prepare her students to become critical citizens who could understand and challenge power-laden social structures. However, she was careful in order to avoid taking a partisan role to create a nondiscriminatory classroom environment. Lauren questioned if using her institutionally given power as a teacher to disrupt power relations in the society could be considered as justice. She was concerned about the possibility that she could marginalize some students' "voices" if she made her political opinions explicit in her class.

The competing discourses that were available and somewhat persuasive to Lauren constructed the conflict: becoming a critical and unbiased teacher. She sought to address this conflict through an instructional approach named "the Upstanders Conference" in which students could think about various issues deeply, stand up for their own beliefs, and respect different opinions without necessarily knowing their teachers' opinions. By making social issues less explicit and spotlighting student opinions, rather than hers, in discussions, Lauren could partially fulfill the incompatible desires and demands. Lauren slightly changed how she thought about teaching for social justice in order to be a critical and unbiased teacher. She refracted the discourse of social justice education so that she could promote "the ideals of participatory democracy" and, simultaneously tackle "the realities of social inequality" (Boler, 2004, p. viii).

\section{Conclusion}

A number of teacher education programs seek to prepare teachers who are committed to promotion of "social justice" while great variation in the use of the term exists. However, there is a paucity of follow-up studies that explore teaching experiences of graduates from teacher education programs that foreground social justice. This study is one of the few follow-up studies. In this qualitative case study, I have examined teaching experiences of one teacher who graduated from a social justice-oriented preservice program in the U.S. My analysis of the teacher's case demonstrates that the competing discourses circulating in the school produced significantly different ideas of what a "good" teacher is and does; the differences con- 
stituted through the discourses created contradictions affecting the teacher's lived experiences. It also shows that the teacher dealt with the dilemma by re-interpreting the discourses that she found limiting. This study confirms and extends the exiting body of research as it sheds lights on how the teachers' experiences were shaped by and, simultaneously, re-framed the discourses surrounding her.

I make some suggestions for future directions. First of all, we, as teacher educators and researchers, need more "teacher stories" that examine the lives of teachers who encounter conflicting demands and desires. We can explore the opportunities that postfoundational theories create to examine the complex ways in which teachers interpret and cope with the conflicts. It would be interesting to research a teacher or a group of teachers over a long period of time across their career span to examine potential long-term consequences associated with teaching practices and the effects of cross-situational changes. Studying a teacher network that aims to reform educational systems can also provide some important insights not found by researching individual teachers. Moreover, teachers can engage in teacher action research to document and analyze their own teaching experiences including how they cope with conflicting demands and desires; or, teachers and teacher educators can collaborate in an inquiry on this issue. This type of research, where teachers participate as researchers, might produce different knowledge than the traditional form of educational research where they are positioned as informants. This type of research can also help us examine how intentions and effects of teachers' practices are (dis)connected in complex ways and, thus, offer further conceptual frameworks for understanding and interpreting the issues.

Furthermore, we need to tap into the possibility of teacher stories in teacher education settings. The biggest contradiction that we encounter in this current political and historical context is to prepare teachers who are capable of promoting inclusivity and social justice in schools where conflicting discourses of education circulate. Teacher educators can use teacher stories to initiate discussions about what it means to teach with a commitment to more democratic and socially just teaching. Teacher educators can support prospective teachers to acknowledge the contradiction of enacting their commitments and, yet, avoid becoming closed to possibilities for change. Prospective teachers can recognize how other teachers are engaged in local forms of resistance and what potentials and limits such practices have. They can understand ambivalence and the complexities of working within and against the system. They can learn from other teachers and acknowledge what possibilities they can cultivate as a teacher. They can extend their imagination to devise small and creative ways of leaving their marks on their day-to-day context rather than feeling defeated.

\section{Funding Acknowledgement}

The author received no financial support for the research, authorship, and publication of this article.

\section{Refences}

Agarwal, R., Epstein, S., Oppenheim, R., Oyler, C., \& Sonu, D. (2010). From ideal to practice and back again: Beginning teachers teaching for social justice. Journal of Teacher Education, 61(3), 237-247.

Anyon, J. (1997). Ghetto schooling: A political economy of urban educational reform. New York, NY: Teachers College Press.
Apple, M. (2006). Educating the "right" way: Markets, standards, God, and inequality. New York, NY: Routledge.

Applebaum, B. (2009). Is teaching for social justice a "liberal bias"? Teachers College Record, 111(2), 376-408.

Athanases, S. Z., \& Martin, K. J. (2006). Learning to advocate for educational equity in a teacher credential program. Teaching and Teaching Education, 22, 627-646.

Boler, M. (2004). Editor's introduction: Troubling speech, disturbing silence. In M. Boler (Ed.), Democratic dialogue in education (pp. vii-xi). New York, NY: Peter Lang.

Cahn, S. M. (1988). Introduction. In J. A. Boydston (Ed.), John Dewey: The later works, 1925-1953 (pp. ix - xviii). Carbondale, IL: Southern Illinois University.

Chubbuck, S. M., \& Zembylas, M. (2008). The emotional ambivalence of socially just teaching: A case study of a novice urban school teacher. American Educational Research Journal, 45(2), 274-318.

Cochran-Smith, M. (2005). Researching teacher education in changing times: politics and paradigms. In M. Cochran-Smith \& K. Zeichner (Eds.), Studying teacher education: The report of the AERA panel on research and teacher education (pp. 69-109). Washington, DC: American Educational Research Association.

Cochran-Smith, M. (2008, March). Toward a theory of teacher education for social justice. In Paper presented at The Annual Meetings of the American Educational Research Association, New York, NY.

Cochran-Smith, M., \& Fries, K. (2005). Researching teacher education in changing times: politics and paradigms. In M. Cochran-Smith \& K. Zeichner (Eds.), Studying teacher education: The report of the AERA panel on research and teacher education (pp. 69109). Washington, DC: American Educational Research Association.

Cochran-Smith, M., Shakman, K., Jong, C., Terrell, D. G., Barnatt, J., \& McQuillan, P. (2009). Good and just teaching: The case for social justice in teacher education. American Journal of Education, 115, 347-377.

Darling-Hammond, L. (1997). The right to learn: A blueprint for creating schools that work. San Francisco, CA: Jossey-Bass.

Darling-Hammond, L. (2004). The color line in American education: Race, resources, and student achievement. Du Bois Review, 1, 213-246.

Darling-Hammond, L. (2006). Powerful teacher education: Lessons from exemplary programs. San Francisco, CA: Jossey-Bass.

Dewey, J. (1899). The school and society. Chicago, IL: University of Chicago Press.

Dewey, J. (1902). The child and the curriculum. Chicago, IL: University of Chicago Press.

Dewey, J. (1916). Democracy and Education: An introduction to the philosophy of education. New York, NY: Free Press

Dover, A. G., Henning, N., \& Agarwal-Rangnath, R. (2016). Re-claiming agency: Justice-oriented social studies teachers respond to changing curricular standards. Teaching and Teacher Education, 59, 457-467. 
Fallace, T. D. (2011). Tracing John Dewey's influence on progressive education, 1903-1951: Toward a received Dewey. Teachers College Record, 113(3), 463492.

Ferguson, A. A. (2000). Bad boys: Public schools in the making of black masculinity. Ann Arbor, MI: The University of Michigan Press.

Gay, G. (2000). Culturally responsive teaching: Theory, research and practice. New York, NY: Teachers College Press.

Giroux, H. A. (1997). Pedagogy and the politics of hope: The ory, culture, and schooling. Boulder, CO: Westview Press.

Grant, C. A., \& Agosto, V. (2008). Teacher capacity and social justice in teacher education. In. M. CochranSmith, S. Feiman-Nemser, D. J. McIntyre, \& K. E. Demers (Eds.), Handbook of research on teacher education: Enduring questions in changing contexts (pp. 175-200). New York, NY: Routledge.

Hollins, E. \& Guzman, M. T. (2005). Research on preparing teachers for diverse populations. In M. CochranSmith \& K. Zeichner (Eds.), Studying teacher education: The report of the AERA panel on research and teacher education (pp. 69-109). Washington, DC: American Educational Research Association.

Laats, A. (2014). Saving progressive education from itself. Education Week, 33(23), 20-21.

Ladson-Billings, G. (1995). Toward a theory of culturally relevant pedagogy. American Educational Research Journal, 32(3), 465-491.

Ladson-Billings, G. (2001). Crossing over to Canaan: The journey of new teachers in diverse classrooms. San Francisco, CA: Jossey-Bass.

McDonald, M. \& Zeichner, K. M. (2009). Social justice teacher education. In W. Ayers, T. Quinn, \& D. Stoval (Eds.), Handbook of social justice in education (pp. 611-624). New York, NY: Routledge.

Noddings, N. (1984). Caring: A feminine approach to ethics and moral education. Berkley, CA: University of California Press.

Nieto, S. (2003). What keeps teachers going? New York, NY: Teachers College Press.

Nixon, D. (2010). Discrimination, performance, and recuperation: How teachers and pupils challenge and recover discourses of sexualities in schools. Teaching and Teacher Education, 26, 145-151.

Paugh, P. (2006). Creating a language for teaching. Democracy \& Education, 16(3), 19-24.

Rothstein, R. (2004). Class and schools: Using social, economic, and educational reform to close the BlackWhite achievement gap. Washington, DC: Economic Policy Institute.

Sleeter, C. E. (2009). Teacher education, neoliberalism, and social justice. In W. Ayers, T. Quinn, \& D. Stovall (Eds.), Handbook of social justice in education (pp. 611-624). New York, NY: Routledge.

Stanley, W. B., \& Nelson, J. L. (1994). The foundations of social education in historical context. In R. A. Martusewicz, \& W. M. Reynolds (Eds.), Inside/Out: Contemporary critical perspectives in education (pp. 265284). New York, NY: Routledge.
Um, S. J. (2019). Politics of hybridity: Teaching for social justice in an era of standards-based reform. Teaching and Teacher Education, 81, 74-83.

Valle, J. W. \& Connor, D. J. (2011). Rethinking disability: A Disability Studies approach to inclusive practices. New York, NY: McGraw-Hill.

Weiss, S. G., DeFalco, A. A., \& Weiss, E. (2005). M. Progressive $=$ Permissive ? Not according to John Dewey... Subjects Matter! Essays in Education, 14, Retrieved December 21, 2016 from www.usca.edu/essays/ voll42005/defalco.pdf

Zeichner, K. M. (2003). The adequacies and inadequacies of three current strategies to recruit, prepare, and retain the best teachers for all students. Teachers College Record, 105(3), 490-519.

Zeichner, K. M. (2006). Reflections of a university-based teacher educator on the future of college- and university-based teacher education. Journal of Teacher Education, 57(3), 326-340.

Zollers, N., Albert, L., \& Cochran-Smith, M. (2000). In pursuit of social justice: Collaborative research and practice in teacher education. Action in Teacher Education, 22(2), 1-14. 